\title{
O PELNOMOCNICTWIE. PRZYCZYNEK DO ANALIZY PODSTAWOWYCH KONSTRUKCJI CYWILISTYCZNYCH
}

I. Możliwość działania przez zastępcę nie jest niczym nowym, choć dyskusja nad tym zjawiskiem zdaje się nie gasnąćc. Mogłoby się nawet wydawać, że zasadnicze kwestie związane z pełnomocnictwem zostały już wyczerpujaco omówione w polskiej doktrynie prawniczej (ostatnio ukazała się kolejna obszerna monografia poświęcona pełnomocnictwu²). W niniejszym artykule staram się odpowiedzieć na - moim zdaniem wciąż aktualne - pytanie o to, jakie znaczenie dla istnienia pełnomocnictwa ma posiadanie przez mocodawcę kompetencji do bycia zastępowanym oraz kompetencji do dokonania czynności prawnej, do której upoważnił pełnomocnika. W szczególności interesujące jest ustalenie skutków utraty jednej lub drugiej kompetencji już po udzieleniu pełnomocnictwa.

II. Zgodnie $\mathrm{z}$ zapowiedzią na wstępie trzeba rozróżnić dwie kwestie: (1) kompetencję do upoważnienia drugiej osoby do dokonywania w cudzym imieniu czynności prawnych (płaszczyzna ogólna) oraz (2) kompetencję do dokonania czynności prawnej, której dotyczy upoważnienie (płaszczyzna szczególna).

Na płaszczyźnie ogólnej chodzi o przejaw autonomii woli podmiotu prawa cywilnego ${ }^{3}$. Znajduje to odzwierciedlenie w art. $95 \S 1$ k.c. W dużym uproszczeniu można to sprowadzić do zgody na to, aby sytuację prawną mocodawcy kształtował ktoś inny niż on sam. Na tym ma polegać upoważniający skutek czynności prawnej dokonanej przez mocodawcę (czyli skutek udzielenia pełnomocnictwa). Najklarowniej można wytłumaczyć relację między zastępowanym i jego zastępca, odwołując się do „kompetencji” i „stanu związania”. Zastępowany ma kompetencję pierwotną i wyposaża w nią zastępcę, ten uzyskuje więc kompetencję wtórną (pochodna od kompetencji zastępowanego). Co istotne, w zakresie udzielonej kompetencji zastępowany jest związany działaniem zastępcy (stan związania). Zastępca ma zaś możliwość dokonywania czynności prawnej ze skutkiem bezpośrednio dla zastępowanego (lecz nie obowiązek ${ }^{5}$ ), może więc kształtować stosunek cywilnoprawny dla zastępowanego (w imie-

\footnotetext{
${ }^{1}$ Zob. ostatnio szerzej o zastępstwie Jedliński, Jedlińska (2018).

${ }^{2}$ Zob. Widerski (2018).

${ }^{3}$ Tak - choć bez wyraźnego rozróżnienia obu płaszczyzn - w szczególności Gawlik (1985):

${ }^{4}$ Zob. szerzej Gawlik (1985): 733-736. Ostatnio Widerski (2018): 92.

${ }^{5}$ Obowiązek może wynikać ze stosunku podstawowego, np. umowy zlecenia.
} 732. 
niu zastępowanego $)^{6}$. Trzeba przy tym pamiętać, że samo upoważnienie do działania w imieniu mocodawcy nie pozbawia mocodawcy kompetencji do dokonania tej czynności prawnej samodzielnie ${ }^{7}$.

Od razu jednak powstaje watpliwość, czy osoba pozbawiona zdolności do czynności prawnych może ważnie ustanowić dla siebie pełnomocnika, a kwestia braku zdolności do czynności prawnej mocodawcy ma znaczenie wyłącznie dla oceny ważności czynności prawnej dokonanej przez pełnomocnika. Przyznanie takiej kompetencji mocodawcy oznaczałoby, że osoba pozbawiona zdolności do czynności prawnych nie może dokonywać żadnych ${ }^{8}$ czynności prawnych samodzielnie poza wskazaniem kogoś, kto mógłby ich dokonać za nią. Sens takiego rozwiązania jest watpliwy. Pełnomocnik zawsze działa bowiem w granicach kompetencji mocodawcy, więc - już na płaszczyźnie szczegółowej - dokonywana przez niego czynność prawna byłaby nieważna, poza wyjątkiem określonym w art. $14 \S 2$ k.c. (sytuacja zmienia się, gdy pełnomocnika dla osoby pozbawionej zdolności do czynności prawnej ustanawia sam przedstawiciel ustawowy, o czym będzie jeszcze mowa). Ponadto chociaż art. 96 k.c. stanowi wprost tylko o „oświadczeniu reprezentowanego", to dziś powszechnie przyjmuje się, że udzielenie pełnomocnictwa jest czynnościa prawną . Tym samym udzielenie pełnomocnictwa mieści się w hipotezie art. $14 \S 1$ k.c. Zresztą budziłoby wątpliwości rozwiązanie, zgodnie z którym do udzielenia pełnomocnictwa (nawet jeśli pełnomocnik miałby już z niego skorzystać po uzyskaniu przez mocodawcę pełnej zdolności do czynności prawnej) niewymagana byłaby zdolność do czynności prawnych, a do zawarcia umowy powszechnie zawieranej w drobnych bieżacych sprawach życia codziennego już tak (argument z art. 14 § 2 k.c. - bez spełnienia dodatkowych przesłanek, np. wykonania umowy, taka umowa jest nieważna $)^{10}$. Pełnomocnictwo udzielone przez osobę pozbawioną zdolności do czynności prawnych jest więc nieważne, a pełnomocnik takiej osoby działa jako rzekomy pełnomocnik (o takim przypadku na płaszczyźnie szczegółowej będzie jeszcze mowa - zob. pkt IV).

${ }^{6}$ Pełnomocnik może mieć ograniczoną zdolność do czynności prawnych (art. 100 k.c.). Nie korzysta ze swojej kompetencji, lecz mocodawcy. Gdy pełnomocnik jest pozbawiony zdolności do czynności prawnych, nie może korzystać z kompetencji mocodawcy (nie może sam dokonywać czynności prawnych). Może być już tylko posłańcem (przenosić oświadczenie „mocodawcy”).

7 Podobnie udzielenie przez pełnomocnika pełnomocnictwa substytucyjnego nie pozbawia kompetencji pełnomocnika do równoległego reprezentowania mocodawcy.

${ }^{8}$ Artykuł $14 \S 2$ k.c. należy bowiem postrzegać nie jako przyznający osobie pozbawionej zdolności do czynności prawnych warunkową zdolność do czynności prawnych, lecz jako przepis statuujący przesłanki ważności czynności prawnej lub określający przesłanki konwalidacji nieważnej czynności prawnej - tak słusznie: Ernst, Rachwał, Zoll (2013): 222-223. Szerzej przeciwko koncepcji warunkowej i ograniczonej zdolności do czynności prawnej osoby pozbawionej tej zdolności i jednoznacznie za koncepcją konwalidacji nieważnej czynności prawnej - zob. Pazdan (2012): 1094 i 1095.

9 Zob. zamiast wielu Pazdan (2019): 641.

10 Osoba pozbawiona zdolności do czynności prawnych nie może też udzielić pełnomocnictwa do zawarcia umowy powszechnie zawieranej w drobnych bieżących sprawach życia codziennego. Odmiennie Widerski (2018): 135. 
Nie można również zapominać, że zgodnie z art. $95 \S 1$ k.c. czynność prawna może być dokonana przez przedstawiciela, o ile w ustawie nie przewidziano wyjątku lub właściwość czynności prawnej tego nie wyklucza ${ }^{11}$. W tych więc - wyjątkowych - sytuacjach, w których niedopuszczalne jest posłużenie się zastępcą (mimo że mocodawcy przysługuje pełna zdolność do czynności prawnych) ${ }^{12}$, udzielone pełnomocnictwo (np. do sporządzenia testamentu) jest nieważne jako sprzeczne z prawem (art. $58 \S 1$ k.c.) ${ }^{13}$.

Sytuacja się zmienia, gdy mocodawca ma ograniczoną zdolność do czynności prawnych (jest małoletni lub ubezwłasnowolniony częściowo). Wtedy bowiem może udzielić pełnomocnictwa bez zgody przedstawiciela ustawowego, nawet jeśli do dokonania czynności prawnej, do której upoważniony jest pełnomocnik, niezbędne jest zezwolenie sądu opiekuńczego. Wynika to stąd, że czynność prawna polegająca na udzieleniu pełnomocnictwa nie polega ani na zaciągnięciu zobowiązania, ani rozporządzeniu prawem, więc nie znajdują do niej zastosowania art. 17 i art. 19 k.c. ${ }^{14}$

Na płaszczyźnie szczegółowej chodzi już tylko o to, czy mocodawca posiada kompetencję do dokonania czynność prawnej, do której dokonania upoważnia pełnomocnika (kompetencja mocodawcy ma swoje źródło w jego zdolności do czynności prawnych lub także w prawie podmiotowym, które mu przysługuje). To, czy ta kompetencja przysługuje mocodawcy, ma znaczenie dla oceny ważności lub skuteczności czynności prawnej dokonanej przez pełnomocnika, zatem - jak zostanie niżej wykazane - nie ma znaczenia w chwili udzielenia pełnomocnictwa, lecz dopiero w chwili dokonania czynności prawnej dla mocodawcy.

Sumując powyższe, należy zatem przyjąć, że na płaszczyźnie ogólnej każdy podmiot prawa cywilnego, któremu przysługuje zdolność do czynności prawnych (choćby ograniczona - o czym będzie jeszcze mowa), ma możliwość nie tylko samodzielnego kształtowania stosunków cywilnoprawnych za pomoca czynności prawnych (płaszczyzna szczegółowa), lecz może też posłużyć się zastępcą i ukształtować swój stosunek cywilnoprawny z pomoca kogoś innego (płaszczyzna ogólna).

III. Udzielenie pełnomocnictwa jest jednostronną czynnościa prawna ${ }^{15}$, czyli mocodawca własnym oświadczeniem woli wywołuje skutki prawne, które w tym wypadku polegają na wyposażeniu pełnomocnika w kompetencję do dokonania czynności prawnej w imieniu mocodawcy i ze skutkiem bezpośrednio dla niego. Do powstania pełnomocnictwa nie jest potrzebne przyjęcie oświad-

11 Zob. szerzej Smyk (2010): 255-266.

${ }_{12}$ Przykładowo nie jest możliwe sporządzenie testamentu przez przedstawiciela (art. 944 $\S 2$ k.c.).

13 Nawet więc wtedy, gdyby ustawodawca zniósł zakaz, o którym mowa w art. $944 \S 2$ k.c., pełnomocnictwo nie „odżywałoby”, a ten, kto sporządzałby - po wejściu nowego prawa w życie w cudzym imieniu testament, byłby rzekomym pełnomocnikiem.

${ }_{14}$ Tak słusznie Ernst, Rachwał, Zoll (2013): 239. Por. niejasno Widerski (2018): 135-136.

15 Zob. w szczególności Gawlik (1985): 783 oraz Pazdan (2019): 641. Por. Widerski (2018): 332-334. Autor przedstawia też alternatywne koncepcje, choć odnoszące się głównie do pełnomocnictwa procesowego. 
czenia o udzieleniu pełnomocnictwa przez pełnomocnika ${ }^{16}$. Mimo wyposażenia przez mocodawcę konkretnej osoby w kompetencję do dokonywania czynności prawnych przyjmuje się, że jego oświadczenie nie jest składane pełnomocnikowi (pełnomocnik nie jest adresatem tego oświadczenia) ${ }^{17}$. Teoretycznie możliwa jest więc sytuacja, w której pełnomocnik zachowa się w granicach umocowania, o którym nic nie wie (mimo subiektywnego przekonania o tym, że działa jako rzekomy pełnomocnik, będzie obiektywnie działał jako rzeczywisty pełnomocnik $\left.^{18}\right)^{19}$. Pełnomocnictwo jest jednak jawne w takim znaczeniu, że pełnomocnik musi ujawnić wobec swojego kontrahenta wolę działania za mocodawcę i (choćby domniemane) granice umocowania ${ }^{20}$. Kontrahent może też od mocodawcy znać treść umocowania pełnomocnika (istotne jest jednak, aby oświadczenie woli pełnomocnika było składane w cudzym imieniu). Nawet więc jeśli pełnomocnik i jego kontrahent nie wiedzą nic o rzeczywistym pełnomocnictwie (o pełnomocnictwie mogą wiedzieć inne osoby), a pełnomocnik działa - w swoim subiektywnym przekonaniu - jako rzekomy pełnomocnik, to czynność prawna będzie ważna, jeśli tylko odpowiada treści pełnomocnictwa. O pełnomocnictwie nie można więc mówić wtedy, gdy kontrahent nie wie, że osoba, z którą dokonuje czynności prawnej, działa jako zastępca innej osoby (wtedy zastępca mógłby być np. zastępcą pośrednim, nawet jeśli bezpośrednio oddziaływałby na majątek zastępowanego - tak dzieje się np. przy zleceniu i komisie sprzedaży).

Udzielenie pełnomocnictwa jest traktowane jako czynność prawna upoważniająca (ostatnio nawet: kompetencyjna ${ }^{21}$ ). Nie mieści się bowiem w defini-

${ }_{16}$ Odmiennie jednak Widerski (2018): 335, 346-347, 349-359, co wynika m.in. z próby jednolitego traktowania pełnomocnictwa na gruncie prawa materialnego i procesowego (ibidem: $339,360)$ i pomieszania dwóch płaszczyzn: prywatno- i publicznoprawnej (koncepcja przyjęcia pełnomocnictwa ma właśnie umożliwić uniknięcie problemów powstających głównie na gruncie regulacji publicznoprawnych - s. 345, np. wskazany przez autora brak możliwości łączenia funkcji prokurenta i członka rady nadzorczej w spółkach kapitałowych). Pełnomocnictwo nie jest też dysfunkcjonalne (jak twierdzi Widerski) przez to, że może powstać bez zawiązania stosunku podstawowego, a samo udzielenie pełnomocnictwa jest jednostronną czynnością prawna. Nie ma potrzeby spoglądania na pełnomocnictwo „w duchu zmodyfikowanej w kierunku konsensualnym koncepcji jednostronnej”. Wydaje się, że w ten sposób Widerski próbuje scalić na powrót pełnomocnictwo ze stosunkiem podstawowym (zobowiązaniowym). Zob. Widerski: 347-349. Podobnie za koniecznością przyjęcia pełnomocnictwa opowiada się m.in. Grykiel (2018).

${ }_{17}$ Zob. Gawlik (1985): 783-784, który przyjmuje, że oświadczenie mocodawcy o udzieleniu pełnomocnictwa może być złożone albo pełnomocnikowi, albo osobie trzeciej, a nawet skierowane do nieoznaczonego kręgu osób. „[...] zakomunikowanie pełnomocnikowi oświadczenia mocodawcy stanowi faktyczną przesłankę działania, a nie prawną przesłankę kompetencji do działania w imieniu mocodawcy" (ibidem: 784). Por. ostatnio Widerski (2018): 430-434, którego zdaniem pełnomocnik jest adresatem oświadczenia mocodawcy o udzieleniu pełnomocnictwa.

18 Zob. Pazdan (2019): 642-643.

${ }^{19}$ Sytuację taką zdaje się wykluczać Widerski (2018): 428, 430 i 435, który podkreśla, że aby pełnomocnik mógł działać, musi wiedzieć o udzieleniu mu pełnomocnictwa (mieć „świadomość umocowania").

${ }^{20}$ Przyjmując koncepcję Grzybowskiego, zgodnie z którą udzielenie pełnomocnictwa jest jednostronną czynnością prawną niewymagająca skierowania do adresata (Grzybowski 1985: 486), nie należy tego mylić z zamanifestowaniem oświadczenia woli osobom trzecim; np. pełnomocnictwo udzielone przez mocodawcę ustnie w pustym pokoju nie wywoła skutków prawnych.

${ }^{21}$ Tak (bez odwołania się do czynności prawnej upoważniającej) Ernst, Rachwał, Zoll (2013): 68 i 229. Por. jednak Widerski (2018): 298. 
cji czynności zobowiąującej ani rozporządzającej22. Czynność upoważniająca samodzielnie nie prowadzi do powstania żadnych obowiązków po stronie osoby upoważnionej ${ }^{23}$. Pełnomocnik ma więc możliwość oddziaływania na sferę prawną mocodawcy, ale nie ma takiego obowiązku. Ze swej istoty wyposażenie pełnomocnika w kompetencję samo w sobie jeszcze nic nie znaczy. Zaczyna bowiem mieć sens dopiero w chwili dokonywania przez niego czynności prawnej. I tu pojawia się pierwsza wątpliwość dotycząca skutków czynności upoważniającej.

Na płaszczyźnie ogólnej ważność pełnomocnictwa oceniamy na chwilę jego dokonania. Jeśli więc osoba ograniczona w zdolności do czynności prawnych lub o pełnej zdolności do czynności prawnych udziela pełnomocnictwa, to jest ono ważne i skuteczne. Jego dalsze istnienie - w razie pozbawienia mocodawcy zdolności do czynności prawnych - jest jednak pozbawione sensu z tych samych powodów, dla których nie powinno się dopuścić ustanowienia pełnomocnika przez osobę pozbawioną zdolności do czynności prawnych. Utrata przez mocodawcę zdolności do czynności prawnych powinna więc równocześnie i automatycznie prowadzić do utraty kompetencji po stronie pełnomocnika do reprezentowania mocodawcy ${ }^{24}$. Nie ma jednak podstaw, aby w takim przypadku sięgać do art. 14 § 1 k.c. Czynność prawna wywołała już swój skutek upoważniajacy i była ważna. Nowy stan faktyczny - w postaci pozbawienia mocodawcy zdolności do czynności prawnych - nie wpływa już na dokonaną czynność prawną. Wygaśnięcie pełnomocnictwa nie może więc być utożsamiane z jego nieważnością.

Za wygaśnięciem pełnomocnictwa przemawia przede wszystkim to, że pełnomocnik nie ma kompetencji przedstawiciela ustawowego do dokonywania czynności prawnych w imieniu mocodawcy, lecz kompetencję samego mocodawcy. Skutki dokonanej przez pełnomocnika czynności prawnej musiałyby więc być tożsame ze skutkami czynności prawnej zdziałanej przez samego mocodawcę, czyli co do zasady czynność prawna byłaby nieważna (art. $14 \S 1$ k.c.). Wymaganie, aby przedstawiciel ustawowy - o ile wiedziałby o pełnomocnictwie - miał odwoływać pełnomocnictwo, by wygasło, jest w tym wypadku co najmniej nadmierne ${ }^{25}$. Wygaśnięcie pełnomocnictwa najlepiej też chroni inte-

22 Zob. w szczególności Grzybowski (1985): 494. Zob. też ostatnio Widerski (2018): 327. Por. jednak nietracące na aktualności uwagi krytyczne co do koncepcji czynności upoważniających Sołtysińskiego (1985): 323-325.

${ }^{23}$ Nie jest więc jasne stanowisko Widerskiego (2018): 435, zgodnie z którym: „[...] z przyjęciem pełnomocnika [pełnomocnictwa? - M.K.] powiązane są skutki prawne, które wpływaja również na sferę prawną mocodawcy, np. odpowiedzialność kontaktowa [kontraktowa? - M.K.] pełnomocnika już z samego tylko pełnomocnictwa”.

${ }^{24}$ Tak Fabian (1963): 116, który przyjmował, że pełnomocnictwo traci swą moc, gdy mocodawca traci zdolność do czynności prawnych, ponieważ „kto [...] nie ma zdolności do czynności prawnych, ten nie może też dokonać czynności prawnej ani sam, ani przez pełnomocnika - lecz musi go zastępować przedstawiciel ustawowy”. Odmiennie Grzybowski (1974): 626, przyp. 69 (bez uzasadnienia) i Smyk (2010): 392. Podobnie też - z powołaniem się na Longchamps de Bériera - Widerski (2018): 136.

25 Zob. w szczególności Smyk (2010): 392 oraz Widerski (2018): 136. 
resy mocodawcy i nie ma w związku z tym potrzeby odwoływania się do art. 58 $\S 2$ k.c. ${ }^{26}$

To, że pełnomocnik ma kompetencję, a nie obowiązek, do reprezentowania mocodawcy i może skorzystać z tej kompetencji już po odzyskaniu zdolności do czynności prawnych przez mocodawcę, nie ma znaczenia dla ustalenia, czy pełnomocnictwo wygasa, ostatecznie bowiem chodzi o możliwość reprezentowania mocodawcy w czasie, gdy ten był pozbawiony zdolności do czynności prawnych. Utrzymywanie takiego pełnomocnictwa na bliżej nieokreślona przyszłość jest bezcelowe. Można by ewentualnie rozważyć „zawieszenie” takiego pełnomocnictwa na czas ubezwłasnowolnienia całkowitego. Lepszym z perspektywy interesów mocodawcy - rozwiązaniem jest jednak wygaśnięcie pełnomocnictwa i jego ustanowienie po odzyskaniu przez mocodawcę (choćby ograniczonej) zdolności do czynności prawnych.

Również to, że co do zasady stosunek podstawowy dla pełnomocnictwa nie wygasa automatycznie $\mathrm{z}$ racji utraty przez mocodawcę zdolności do czynności prawnych (np. zlecenie - art. 747 zd. pierwsze k.c.), nie przemawia przeciwko wygaśnięciu samego pełnomocnictwa. Chodzi bowiem o to, by umożliwić przedstawicielowi potwierdzenie czynności prawnej dokonanej przez np. zleceniobiorcę (brak wygaśnięcia tego pełnomocnictwa prowadziłby do dalszych wątpliwości - można by bowiem wtedy twierdzić, że pełnomocnik taki może bez zgody przedstawiciela ustawowego dokonywać czynności prawnych, dla których nie jest potrzebne zezwolenie sądu opiekuńczego - twierdzenie, że może dokonywać czynności określonych tylko w art. 14 § 2 k.c. podważałoby bowiem sens istnienia takiego pełnomocnictwa).

Za wygaśnięciem pełnomocnictwa (automatyczną utratą kompetencji do reprezentowania) przemawia też argument z przeciwieństwa, odnoszacy się do art. $109^{7} \S 4$ k.c. - zgodnie z jego obecnym brzmieniem ${ }^{27}$ utrata przez przedsiębiorcę zdolności do czynności prawnych nie powoduje wygaśnięcia proku$\mathrm{ry}^{28}$. Przeciwne stanowisko czyniłoby ten przepis zbędnym.

Podsumowujac dotychczasowe rozważania, pozbawienie mocodawcy zdolności do czynności prawnych powoduje wygaśnięcie pełnomocnictwa (co do art. 105 k.c. - zob. dalsze uwagi).

${ }^{26}$ Odmiennie Smyk (2010): 392, którego zdaniem z uwagi na niewygasanie pełnomocnictwa dopiero art. 58 § 2 k.c. w dostateczny sposób zabezpiecza interesy ubezwłasnowolnionego mocodawcy, choć autor nie tłumaczy tego, w jaki sposób dokładnie.

27 Zmienionym ustawą z 5 lipca 2018 r. o zarządzie sukcesyjnym (Dz. U. poz. 1629), która weszła w życie 25 listopada 2018 r. Przed tą datą w świetle art. $109^{7} \S 4$ k.c. śmierć przedsiębiorcy ani utrata przez niego zdolności do czynności prawnych nie powoduje wygaśnięcia prokury. Przepis ten - w brzmieniu sprzed 25 listopada 2018 r. - zreszta przestał być martwy dopiero od 30 kwietnia 2018 r., kiedy weszła w życie ustawa z 6 marca 2018 r. - Przepisy wprowadzające ustawę - Prawo przedsiębiorców oraz inne ustawy dotyczące działalności gospodarczej (Dz. U. poz. 650), która zmieniła m.in. art. $109^{1} \S 1$ k.c. i tym samym przesądziła o tym, że prokury może udzielić przedsiębiorca podlegającego obowiązkowi wpisu do Centralnej Ewidencji i Informacji o Działalności Gospodarczej (zatem osoba fizyczna). Zob. co do znaczenia art. $109^{7} \S 4$ k.c. przed 30 kwietnia 2018 r. - np. Szwaja, Mika (2009): 901; Osajda (2017).

28 Tak Soczyński (2005): 120. 
IV. Jeśli kompetencja pierwotna ma swoje źródło w zdolności do czynności prawnych, to pojawia się pytanie o jej przysługiwanie w sytuacji, gdy mocodawca ma ograniczona zdolność do czynności prawnych (jest małoletni lub ubezwłasnowolniony częściowo). Nie ma wątpliwości, że poza zakresem zainteresowania przedstawiciela ustawowego mocodawcy są te czynności prawne dokonane przez pełnomocnika, do których dokonania mocodawcy przysługuje pełna zdolność do czynności prawnych (art. 20-22 k.c.). Jeśli zaś chodzi o te sytuacje, w których do ważności czynności prawnej niezbędna jest zgoda przedstawiciela ustawowego, to konsekwentnie należy stwierdzić, że czynność prawna dokonana przez pełnomocnika w imieniu osoby ograniczonej w zdolności do czynności prawnych wywołuje skutki takie, jakby mocodawca działał samodzielnie. Trzeba rozróżnić trzy sytuacje (dotyczace dwustronnej czynności prawnej - oczywiście jednostronna czynność prawna, do której ustawa wymaga zgody przedstawiciela ustawowego, dokonana zarówno przez mocodawcę ograniczonego w zdolności do czynności prawnych, jak i jego pełnomocnika jest w świetle art. 19 k.c. nieważna).

Pierwsza - przedstawiciel ustawowy mógł wyrazić zgodę na dokonanie czynności prawnej bez uprzedniego zezwolenia sądu ${ }^{29}$. W takiej sytuacji dokonana przez pełnomocnika, powołanego przez osobę ograniczoną w zdolności do czynności prawnych, czynność prawna jest bezskutecznie zawieszona (może stać się ważną i skuteczną albo nieważną - w zależności od tego, czy przedstawiciel ustawowy potwierdzi ją na podstawie art. $18 \S 1$ k.c. lub osoba ograniczona w zdolności do czynności prawnych potwierdzi ją na podstawie art. 18 $\S 2$ k.c. po uzyskaniu pełnej zdolności do czynności prawnych) ${ }^{30}$.

Druga - przedstawiciel ustawowy do wyrażenia zgody na dokonanie czynności prawnej potrzebował (uprzedniego) zezwolenia sądu ${ }^{31}$. W takiej sytuacji czynność prawna dokonana przez pełnomocnika, powołanego przez osobę ograniczoną w zdolności do czynności prawnych, jest jednak również bezskutecznie zawieszona, ponieważ zezwolenie sądu dotyczy tylko pośrednio czynności prawnej dokonywanej przez zastępowanego, a bezpośrednio zgody przedstawiciela ustawowego na jej dokonanie (zgody, która może być również udzielona po dokonaniu czynności prawnej zgodnie z art. $18 \S 1$ k.c. $)^{32}$. Skutki czynności prawnej dokonanej przez pełnomocnika są więc takie, jakie są skutki czynności prawnej dokonanej przez samego mocodawcę (osobę ograniczona w zdolności do czynności prawnych ${ }^{33}$.

29 Zob. art. $101 \S 3$, art. 156, art. 175 w zw. z art. 156 i art. $178 \S 2$ w zw. z art. 156 ustawy z 25 lutego 1965 r. - Kodeks rodzinny i opiekuńczy (Dz. U. 2017, poz. 682 ze zm.; dalej jako: k.r.o.).

${ }^{30}$ Por. Widerski (2018): 136, który - po pierwsze - nie rozróżnia opisanej w niniejszym artykule płaszczyzny ogólnej i szczegółowej, a - po drugie - nie rozróżnia sytuacji, w których przedstawiciel ustawowy do dokonania czynności prawnej powinien uzyskać zezwolenie sądu i w związku z tym w każdej sytuacji niesłusznie traktuje pełnomocnika jako rzekomego.

31 Zob. art. $101 \S 3$, art. 156 , art. 175 w zw. z art. 156 i art. $178 \S 2$ w zw. z art. 156 k.r.o.

32 Zob. zamiast wielu Słyk (2019).

33 Zachowuje w tym względzie aktualność uchwała Pełnego Składu Izby Cywilnej Sądu Najwyższego z 24 czerwca 1961 r., 1 CO 16/61, OSNCP 1963 nr 9, poz. 187 - w której SN na gruncie ustawy - Przepisy ogólne prawa cywilnego z 18 lipca 1950 r. (Dz.U. Nr 34, poz. 311) stwierdził m.in., że czynność prawna dwustronna, dokonana przez małoletniego ograniczonego w zdolności do czynności prawnych (tu: jego pełnomocnika) bez wymaganej prawem zgody przedstawiciela 
Trzecia - pełnomocnik został ustanowiony przez przedstawiciela ustawowego, a przedstawiciel ustawowy do dokonania czynności prawnej za osobę ograniczoną w zdolności do czynności prawnych potrzebował (uprzedniego) zezwolenia sądu ${ }^{34}$. W takiej sytuacji - na płaszczyźnie ogólnej - przedstawiciel ustawowy ma (tak jak reprezentowana przez niego osoba ograniczona w zdolności do czynności prawnych) kompetencję do upoważnienia kogokolwiek do zastępowania osoby ograniczonej w zdolności do czynności prawnych. Istotne jest bowiem to, że pełnomocnik reprezentuje nie przedstawiciela ustawowego, lecz osobę ograniczoną w zdolności do czynności prawnych, a ta ma kompetencję (na płaszczyźnie ogólnej) do powołania pełnomocnika. Ponownie więc - już na płaszczyźnie szczegółowej - czynność prawna dokonana przez pełnomocnika jest bezskutecznie zawieszona, a nie od razu nieważna. Przedstawiciel ustawowy dopiero po uzyskania orzeczenia sądowego potwierdzi czynność prawną dokonaną przez rzekomego pełnomocnika. Gdyby przedstawiciel sam dokonywał czynności prawnej, na którą potrzebowałby uprzedniego zezwolenia sądu opiekuńczego, to czynność ta byłaby od razu nieważna na podstawie art. 58 § 1 k.c. (sprzeczna z art. $101 \S 3$ k.r.o.). Pełnomocnik - nawet powołany przez przedstawiciela ustawowego bez zgody lub wiedzy mocodawcy - reprezentuje mocodawcę, a nie jego przedstawiciela ustawowego, dlatego skutki czynności prawnej pełnomocnika muszą być takie, jak wtedy gdy pełnomocnictwa udzielił mu sam mocodawca (z zastrzeżeniem sytuacji, o której poniżej).

Sytuacja komplikuje się nieco, gdy mocodawca jest pozbawiony zdolności do czynności prawnych. Gdy brak zdolności do czynności prawnych jest pierwotny (chodzi więc głównie o małoletniego poniżej 13 roku życia, choć również o ubezwłasnowolnionego całkowicie, który dopiero po ubezwłasnowolnieniu chce udzielić pełnomocnictwa), to - jak zostało to wyjaśnione - małoletni (ubezwłasnowolniony całkowicie) nie może udzielić pełnomocnictwa (udzielenie pełnomocnictwa jest nieważne i osoba powołana jako pełnomocnik jest rzekomym pełnomocnikiem). To nie dotyczy jednak jego przedstawiciela ustawowego, który może posłużyć się pełnomocnikiem przy dokonywaniu czynności prawnej w imieniu małoletniego (udziela pełnomocnictwa przedstawiciel ustawowy, lecz reprezentowanym bezpośrednio jest małoletni ${ }^{35}$ ). Gdy pełnomocnika powołuje przedstawiciel ustawowy osoby pozbawionej zdolności do czynności prawnych, to z pełnomocnikiem dzieli się swoją kompetencja, o treści wyznaczonej w szczególności przez art. 101 lub art. 156 k.r.o. (również odpowiednio stosowany na podstawie art. 175 i art. $178 \S 2$ k.r.o.). Pełno-

ustawowego, może być konwalidowana przez potwierdzenie czynności bądź przez przedstawiciela ustawowego, gdy chodzi o czynność objętą dyspozycją art. 58 § 1 i 85 ustawy - Kodeks rodzinny z 27 czerwca 1950 r. (Dz. U. Nr 34, poz. 308), za uprzednim zezwoleniem władzy opiekuńczej na takie potwierdzenie, bądź przez małoletniego po uzyskaniu przez niego pełnej zdolności do czynności prawnych (przywołane art. 58 § 1 miał podobną treść do art. $101 \S 3$ k.r.o.).

${ }^{34}$ Chodzi o czynności przekraczające zakres zwykłego zarządu majątkiem dziecka lub w ważniejszych sprawach dotyczących zarządu majątkiem podopiecznego lub kuranta. Zob. art. $101 \S 3$, art. 156 , art. $175 \mathrm{w}$ zw. z art. $156 \mathrm{i}$ art. $178 \S 2 \mathrm{w}$ zw. z art. 156 k.r.o.

${ }^{35}$ Zob. Smyk (2010): 396-397. 
mocnik może więc dokonać czynności prawnej takiej, jakiej sam - w imieniu osoby reprezentowanej przez przedstawiciela ustawowego - może dokonać przedstawiciel ustawowy (może więc m.in. zawrzeć umowę należącą do umów powszechnie zawieranych w drobnych bieżących sprawach życia codziennego i umowa ta jest ważna niezależnie od jej wykonania). Jeśli dla danej czynności niezbędne jest zezwolenie sądu opiekuńczego, to czynność ta dokonana przed uzyskaniem takiego zezwolenia będzie nieważna (nie będzie podlegała potwierdzeniu). Traktujemy ją bowiem tak samo, jak czynność dokonana przez przedstawiciela ustawowego bez wymaganego zezwolenia sądu opiekuńczego. Przedstawiciel ustawowy ma jednak - tak jak osoba o ograniczonej zdolności do czynności prawnych - możliwość powołania pełnomocnika, zanim jeszcze uzyska zezwolenie sądu opiekuńczego na dokonanie czynności prawnej, do której pełnomocnika upoważnia.

Gdy brak zdolności do czynności prawnych mocodawcy jest wtórny (ubezwłasnowolnienie całkowite mocodawcy), to - jak zostało to również wyjaśnione - pełnomocnictwo wygasa. Nie może znaleźć zastosowanie art. 105 k.c., gdyż działanie pełnomocnika odbywałoby się $\mathrm{w}$ granicach uprzedniego umocowania, a więc czynność prawna dokonana przez niego musiałaby być nieważna. Pełnomocnik działa więc wtedy jako rzekomy pełnomocnik i w zależności od rodzaju dokonanej przez niego czynności prawnej - czynność ta będzie od razu nieważna (przedstawiciel ustawowy nie mógł bez uprzedniego zezwolenia sądu dokonać czynności prawnej, np. rozporządzić istotnym składnikiem majątku małoletniego) lub bezskutecznie zawieszona (przedstawiciel ustawowy mógł dokonać samodzielnie czynności prawnej bez uprzedniego zezwolenia sądu opiekuńczego, np. zakupić dla małoletniego podręczniki do nauki). Do potwierdzenia czynności prawnej znajdzie jednak zastosowanie art. 103 k.c., a nie - jak w wypadku pełnomocnika osoby ograniczonej w zdolności do czynności prawnych - art. 18 k.c. Trzeba bowiem powtórzyć, że przedstawiciel może powołać pełnomocnika dla osoby pozbawionej zdolności do czynności prawnych i pełnomocnik ten może dokonać czynności prawnej w zakresie kompetencji przedstawiciela. Jeśli więc pełnomocnictwo udzielone jeszcze przez mocodawcę wygaśnie w wyniku utraty przez mocodawcę zdolności do czynności prawnych, a rzekomy pełnomocnik dokona czynności prawnej, której mógłby - bez uprzedniego zezwolenia sądu - dokonać sam przedstawiciel, to przedstawiciel może potwierdzić tę czynność (również bez zezwolenia sądu opiekuńczego). Czynność taka będzie zatem do czasu jej potwierdzenia bezskutecznie zawieszona i stanie się nieważną dopiero w razie odmowy jej potwierdzenia lub upływu terminu do jej potwierdzenia (art. $103 \S 1$ i 2 k.c.).

V. Powstaje zresztą ogólniejsze i podstawowe zarazem pytanie o wpływ dokonania czynności prawnej przez mocodawcę na dalsze trwanie pełnomocnictwa $^{36}$. Jeśli udzielono pełnomocnikowi pełnomocnictwa szczególnego, np. do

${ }^{36}$ Większość autorów, gdy pisze o wygaśnięciu pełnomocnictwa w wyniku dokonania czynności prawnej, do której zostało udzielone, ma na myśli dokonanie jej przez pełnomocnika, a nie mocodawcę - np. jak się zdaje: Widerski (2018): 197; Smyk (2010): 384. 
sprzedaży tej samej rzeczy, a mocodawca sprzedał ją samodzielnie, to możliwe są dwa rozwiązania.

Pierwsze - pełnomocnictwo wygasa, ponieważ było pełnomocnictwem szczególnym, a czynność prawna, do której było udzielone, została już dokonana. To rozwiązanie zakłada, że czynność, do której jest umocowany pełnomocnik, można dokonać tylko raz (osoba trzecia będzie chroniona jednak, jeśli będą spełnione przesłanki określone w art. 105 k.c.). Niemniej trzeba pamiętać, że jeśli jest to (przykładowo) umowa sprzedaży, to nawet uprzednie sprzedanie rzeczy przez mocodawcę nie powoduje wyłączenia jego kompetencji do zawarcia kolejnych umów sprzedaży tej samej rzeczy (nie chodzi o wielokrotną sprzedaż tej samej rzeczy przez pełnomocnika). Nie należy tego mylić z pełnomocnictwem rodzajowym (ponieważ nadal chodzi nie o umocowanie do sprzedawania różnych rzeczy należących do mocodawcy, lecz do sprzedania określonej, konkretnej rzeczy). Mocodawca - jeśli chce samodzielnie dokonać czynności prawnej - powinien albo odwołać pełnomocnictwo, aby ustrzec się ewentualnego równoległego lub późniejszego dokonania czynności prawnej przez pełnomocnika, albo np. zastrzec w treści pełnomocnictwa warunek rozwiąujący (pełnomocnictwo wygaśnie, jeśli mocodawca lub inny pełnomocnik dokona czynności prawnej określonej w pełnomocnictwie).

Drugie - pełnomocnictwo nie wygasa (automatycznie). Oczywiście umowa sprzedaży, którą zawrze pełnomocnik, wywoła skutki zobowiązujące, choć jeśli byłyby spełnione przesłanki ochrony nabywcy od nieuprawnionego (art. 169 k.c.), to nabywca uzyska własność od pełnomocnika (istotne będzie przede wszystkim posiadanie rzeczy przez pełnomocnika i wydanie jej nabywcy). To spowoduje utratę własności przez kupującego, który wcześniej zawarł umowę bezpośrednio z mocodawca.

Należy opowiedzieć się za drugim z przedstawionych rozwiązań. Brak podstawy, aby uznać, że pełnomocnictwo (automatycznie) wygasa tylko dlatego, że sam mocodawca lub inny z jego pełnomocników dokonał czynności prawnej. Wystarczające zabezpieczenie interesów mocodawcy gwarantuje mu możliwość odwołania pełnomocnictwa lub zastrzeżenia w treści pełnomocnictwa warunku rozwiązującego.

VI. Oddzielenie płaszczyzny ogólnej od szczególnej w wypadku pełnomocnictwa ułatwia zrozumienie, że czym innym jest samo udzielenie pełnomocnictwa, a czym innym czynność prawna dokonana przez pełnomocnika w imieniu mocodawcy. Nie ulega więc wątpliwości, że nie-właściciel może upoważnić do dokonania czynności prawnej rozporządzającej co do cudzej rzeczy. Czynność prawna rozporządzająca nie wywoła jednak żadnych skutków, jeśli rzecz w chwili jej dokonania nie należy do mocodawcy ${ }^{37}$, chyba że np. spełnione będa przesłanki określone w art. 169 k.c. (np. umowie zawartej w wykonaniu zobo-

${ }^{37}$ Przykładowo mocodawca zawarł umowę sprzedaży rzeczy o wyłącznie zobowiązujących skutkach, następnie upoważnia pełnomocnika do zawarcia umowy rzeczowej, lecz sprzedaje rzecz komu innemu (nie informując o tym pełnomocnika). Jeśli następnie pełnomocnik zawrze umowę rzeczowa, to - choć ważna - nie wywoła ona żadnych skutków prawnych. 
wiązania do przeniesienia własności przypisze się skutki rzeczowe, których nie mogłaby normalnie wywołać). Umowa ustanawiająca hipotekę, zawarta przez pełnomocnika, jeżeli nieruchomość nie należy do mocodawcy, nie wywoła więc skutków prawnych lub - w razie spełnienia przesłanek rękojmi wiary publicznej ksiag wieczystych - przypiszemy jej skutki rzeczowe i wierzyciel nabędzie hipotekę.

VII. Pełnomocnictwo do dokonania określonej czynności prawnej musi być rozpatrywane na dwóch płaszczyznach: ogólnej i szczególnej. Ta pierwsza odnosi się do samego udzielenia pełnomocnictwa i zdolności do upoważnienia. Ta druga dotyczy zaś zdolności mocodawcy do dokonania czynności prawnej, do której dokonania upoważnił pełnomocnika. Ograniczenie zdolności do czynności prawnych lub utrata prawa podmiotowego (np. własności, autorskich praw majątkowych) nie wpływają na pełnomocnictwo (nie wygasa ono). Pozbawienie mocodawcy zdolności do czynności prawnych prowadzi zaś do wygaśnięcia pełnomocnictwa. Interesy mocodawcy sa przy tym w każdym przypadku należycie chronione: w wypadku utraty zdolności do czynności prawnych przez mocodawcę pełnomocnik działa jako rzekomy pełnomocnik (czynność przez niego dokonana jest nieważna lub bezskutecznie zawieszona i wymaga potwierdzenia przez przedstawiciela ustawowego na podstawie art. $103 \S 1$ k.c.); w wypadku ograniczenia zdolności do czynności prawnych mocodawcy - czynność prawna dokonana przez pełnomocnika podlega kontroli przedstawiciela ustawowego (tak jak czynność dokonana przez osobę ograniczoną w zdolności do czynności prawnych - na podstawie art. $18 \S 1$ k.c.), a niekiedy do swej ważności wymaga również zezwolenia sądu opiekuńczego (art. $101 \S 3$ k.r.o.); w wypadku utraty prawa podmiotowego przez mocodawcę nie będzie co do zasady możliwe rozporządzenie tym prawem.

\section{Michat Kućka}

Uniwersytet Jagielloński w Krakowie

m.kucka@uj.edu.pl

https://orcid.org/0000-0002-4888-2191

Ernst, U., Rachwał A., Zoll, F. (2013). Prawo cywilne. Część ogólna. Warszawa.

Fabian, J. (1963). Pełnomocnictwo. Warszawa.

Gawlik, B. (1985). Przedstawicielstwo, [w:] S. Grzybowski (red.), System prawa cywilnego. Tom 1: Część ogólna. Wrocław-Warszawa-Kraków-Gdańsk-Łódź: 728-790.

Grykiel, J. (2018). Komentarz do art. 96 k.c., nb. 35-38, [w:] M. Gutowski (red.), Kodeks cywilny. Tom 1: Komentarz do art. 1-352. Warszawa: nb. 35-38.

Grzybowski, S. (1974). System prawa cywilnego. Tom 1: Część ogólna. Wrocław-Warszawa-Kraków-Gdańsk.

Grzybowski, S. (1985). Czynności prawne. Zasady ogólne, [w:] S. Grzybowski (red.), System prawa cywilnego. Tom 1: Część ogólna. Wrocław-Warszawa-Kraków-Gdańsk-Łódź: 475-511.

Jedliński, A., Jedlińska, M. (2018). Pojęcie zastępstwa w prawie cywilnym materialnym (artykuł dyskusyjny). Rejent 1(321): 39-64.

Osajda, K. (2017). Komentarz do art. $109^{7}$ k.c., nb. II, [w:] K. Osajda (red.), Tom 1: Kodeks cywilny. Komentarz. Część ogólna. Przepisy wprowadzające KC. Prawo o notariacie (art. 79-95 i 96-99). Warszawa: 796. 
Pazdan, M. (2012). Osoby fizyczne, [w:] M. Safjan (red.), System prawa prywatnego. Tom 1: Prawo cywilne - część ogólna. Warszawa: 1047-1114.

Pazdan, M. (2019). Przedstawicielstwo, [w:] Z. Radwański, A. Olejniczak (red.), System prawa prywatnego. Tom 2: Prawo cywilne - część ogólna. Warszawa: 588-693.

Słyk, J. (2019). Komentarz do art. 101 k.r.o., nb. 25, [w:] K. Osajda (red.), Kodeks rodzinny i opiekuńczy. Komentarz. Legalis/el.

Smyk, M. (2010). Pełnomocnictwo według kodeksu cywilnego. Warszawa.

Soczyński, M. (2005). Wygaśnięcie pełnomocnictwa. Rejent 10(174): 119-131.

Sołtysiński, S. (1985). Czynności rozporządzające. Przyczynek do analizy podstawowych pojęć cywilistycznych, [w:] J. Błeszyński, J. Rajski (red.), Rozprawy z prawa cywilnego. Księga pamiątkowa ku czci Witolda Czachórskiego. Warszawa: 301-330.

Szwaja, J., Mika, I.B. (2009). Prokura, [w:] S. Włodyka (red.), System prawa handlowego. Tom 1: Prawo handlowe - część ogólna. Warszawa: 886-952.

Widerski, P. (2018). Pełnomocnictwo w prawie polskim. Warszawa.

\section{ON THE POWER OF ATTORNEY. AN INTRODUCTION TO AN ANALYSIS OF THE BASIC CONCEPTS OF CIVIL LAW}

\section{Summary}

The power of attorney to perform a particular legal act must be considered on two levels: general and specific. The former refers to granting the power of attorney, thus the capacity of a principal to authorize someone else to represent him or her. The latter relates to the capacity of a principal to perform a legal act to which he or she authorized an attorney-in-fact. Limitation of legal capacity or loss of subjective right (for example property rights) do not affect the power of attorney (it does not expire). The full incapacitation of a principal, however, leads to the expiration of the power of attorney. The interests of the principal are in each case duly protected: in the event of the principal's incapacitation an attorney-in-fact acts as the alleged attorney-in-fact - falsus procurator (the act performed by the alleged attorney-in-fact is void or voidable and its validity depends on confirmation by a statutory representative under Article 103 para. 1 of the Polish Civil Code); in the event of limitation of the legal capacity of the principal (partial incapacitation) - a legal act performed by an attorney-in-fact is subject to the control of a statutory representative (just like an act carried out by a person with limited capacity for legal acts - pursuant to Article 18 para. 1 of the Polish Civil Code) and sometimes also requires authorization for a court (Article 101 para. 3 of the Polish Family and Guardianship Code); in the event of the loss of the subjective right by a principal, a disposition of that right conducted by an attorney-in-fact will generally have no effect (unless for instance the prerequisites for acquisition of that right in good faith are met).

Keywords: power of attorney; expiration of authorization; principal's capacity for legal acts; capacity to authorize; incapacitation of a principal 